\title{
Investigating Controversies in Teaching Grammar: A Case for the Iranian High School Students
}

\author{
Fatemeh Abbasian Boroujeni \\ English Department, University of Isfahan, Isfahan, Iran \\ Email: abbasianf@gmail.com
}

\begin{abstract}
The fact that L2 learners need to learn grammar is now a well- established fact (Celce- Murcia, 1991; Foto, 1994; Sheen, 2003; Davies, 2006; Ellis, 2006; Borg and Burns, 2008; Cullen, 2008). What has remained controversial is 'how to teach grammar to help L2 learners acquire it. The present study was designed on a qualitative-quantitative survey basis using a semi-structured interview and questionnaire on the effectiveness of different approaches in teaching grammar which was administered to 128 students and 5 EFL instructors in four high schools in Isfahan province, the city of Falavarjan. The results of the study revealed that the students and instructors preferred 'focus on form (FonF)' instructional method. The results also demonstrated that some of the participants favored a teacher fronted classroom with an emphasis on explicit grammar instruction. The results of the study is in line with the related literature in grammar teaching approaches that 'focus on form' (FonF) acts as a middle-way between the two extremes of (FonFs) and 'focus on meaning (FonM)'. Moreover, the role of $\mathrm{L1}$ in the grammar instruction cannot be stigmatized as unworthy of consideration without providing enough empirical evidence. The overall results suggest that the treatment of grammar with a 'one -size -fits- all' methodology instead of utilizing a balanced perspective based on the needs and context of the learners is not expected to yield sufficient result in any language teaching contexts.
\end{abstract}

Index Terms-grammar teaching, context, FonFs, FonM, FonF

\section{INTRODUCTION}

Over the centuries, second language educators have alternated between two types of approaches to language teaching i.e., those that focus on analyzing the language and those that focus on using the language. As approaches in language teaching have changed, modifications in methodologies and consequently changes in grammar have emerged but, among different elements in language teaching, grammar teaching has held and continues to hold a central place (Campbell, 1970; Long, 1991; Foto, 1994; Sheen, 2003; Davies, 2006; Ellis, 2006; Borg and Burns, 2008; Cullen, 2008).

According to Sheen (2003) in the last forty years the role of grammar has gone through three main stages: absolute prominence, exclusion, and re-introduction with caution. These three stages have been associated respectively to three different approaches to instruction namely, 'focus on forms (FonFs)', 'focus on meaning (FonM)', and 'focus on form (FonF)'.As the focus of classroom instruction has shifted over the past few decades from an emphasis on language forms to attention to functional language within communicative contexts, the place of grammar instruction i.e., how to teach grammar and what to teach as grammar to help L2 learners acquire it, has become more important. By giving practical examples and types of grammar tasks which exhibit these features, Cullen (2008) reintroduces teaching grammar as a liberating force. These tasks all derive from traditional ELT practice, but have been revitalized to support an approach to emphasize its liberating potential. He identifies three key design features which need to be present in any grammar production tasks, i.e., learner choice over the use of grammatical structures, a process of applying grammar to lexis, and opportunities to make comparisons and notice gaps in their use of grammar. Borg and Burns (2008) identified range of ways in which teachers understood and integrated grammar in the classes. They classified them into two broad orientations labeled as temporal and contextual.

The range of approaches to form can be placed in a long continuum. On one side, are planned, deductive, explicit, intensive, and discrete-point metalinguistic explanations, and on the other end of the continuum are implicit, inductive, unplanned, incidental references to form through noticing and grammar consciousness rising. In this article, different approaches to grammar teaching during the last four decades are reviewed and their application in an EFL context in general, and in the Iranian context in particular has been examined to see what kind of grammar teaching can effectively facilitate language learning.

A. Focus on Forms (FonFs)

According to Laufer and Girsai (2008) focus on forms (FonFs) is an approach equated with traditional method which entails teaching discrete linguistics structures in separate lessons in a sequence determined by syllabus writers. Ellis, 
et.al (2001), also believe that in a (FonFs) approach, students view themselves as learners of a language and the language as the object study. The underlying assumption behind traditional-grammar-teaching is that having learners produce the structures correctly and repeatedly helps them learn it. During the past 40 years, the methodological approaches which have given a central importance to grammar teaching are: Audio-lingual Approach and Cognitive Code Approach.

During 1950s and 1960s Audiolingualism as a reaction to the Grammar Translation Approach and its lack of emphasis on oral-aural skills emerged. Those following the Grammar Translation Method hoped that through explicit and deductive grammar teaching students would become familiar with the grammar of their native language and learn about the target language.

Audio-lingual Approach represented the first attempt by U.S Structural Linguists such as Fries and Lado to influence the teaching of modern foreign languages. For them grammar was viewed as the starting point of language learning. Therefore grammatical structures were very carefully sequenced from basic to more complex. Adopting a behaviorist psychology, they believed that learning is a matter of habit formation. Thus mimicry of forms and memorization of certain sentence patterns were used extensively. A variety of manipulative drill types was practiced with the aim of minimizing learner's errors.

The Cognitive Code Approach, largely a reaction to the behaviorist features of audiolingualism, was influenced by the work of linguists like Chomsky and psychologist like Miller.

Language learning was viewed as hypothesis formation and rule acquisition, rather than habit formation. In this approach, grammar was considered important, and rules were presented either deductively or inductively. Errors were viewed as inevitable by products of language learning. Campbell (1970) also argues for acquiring a native like competence which enables a learner to produce and interpret infinite number of sentences by utilizing a finite number of rulers. Martine (1978) puts forward the concept of spiraling, a systematic revisiting of the same material with increasingly broader and deeper explanations and practice. Grammar-based methodologies based on presentationpractice-production (P-P-P) format favored a teacher- fronted language lesson. In general in this methodology the grammar of a new language is considered as fundamental to the development of competence in that language.

Sheen (2003) believes that a 'focus on forms' is being stigmatized as unworthy of consideration unfairly. He thinks that (FonFs) is perceived as being incompatible with currently-accepted theories by a number of applied linguists who do not provide reliable and supportive empirical evidence for their claim. Sheen (2006) maintains that countless numbers of successful learners owe their success in part to TGT and criticizes Ellis's proscription of traditional grammar teaching.

\section{B. Meaning-focused Instruction (FonM)}

Meaning-Focused Instruction according to Ellis et al. (2001) had two essential elements. First, it required the classroom participants to treat language as a tool for achieving some nonlinguistic goal rather than as abject to be studied for the purpose of learning the language .Second, it demanded the participants to function as users rather than as learners of language. This instructional approach could be manifested in comprehension and communicative approaches

The comprehension approach represented attempts by many language methodologists like Krashen and Terrel during the 1970s and 1980s to recreate the first language acquisition experience for the second/foreign language learners. The prominent notion was that comprehension is primary and should precede any production. It was proposed that a semantically based syllabus be followed and all grammar instruction be excluded from the classroom as the attention was placed solely on meaning. Proponent of this philosophy also believed that error correction was unnecessary or even counterproductive.

The communicative approach originated in the work of anthropological linguists such as Hymes in the U.S and functional linguists like Halliday in Britain all of whom viewed language as an instrument of communication. The syllabus of a language course based on this approach was not organized around grammar but subject matters, tasks, projects, and pragmatic functions. In other words, language instruction was considered content-based, meaningful, contextualized, and discourse-based (rather than sentence-based). Among the proponents of this approach some debate regarding the nature, extent and type of grammar instruction excited.

\section{Focus on Form (FonF)}

'Focus on form' was the result of attempts to find a middle-way between form-focused and meaning-focused instruction, both of which had been deemed by many to be insufficient at promoting acceptable language acquisition (Fotos, 1994; Ellis, 2003, 2006; Davies, 2006; Saraceni, 2007).

As a reaction to Communicative Language Teaching (CLT) which refused to give a systematic role to grammar instruction, Long created Task-Based Language Teaching (TBLT). Focus on Form is described by Long (1991) as the incidental attention that teachers and L2 learners pay to form in the context of meaning focused instruction. Ellis et al, (2001) mention that focus on form occurs in discourse that is predominantly 'meaning centered, observable (i.e., occurs intentionally), extensive (i.e., several different forms may be attended to in the context of a single lesson), and transitory (i.e., occasional so as not to interfere too much with meaning)' (pp. 411-412). Attention to form according to Ellis(2006) can be proactive (i.e., planned) and intensive or reactive (i.e. incidental) and extensive. (FonF) can also be preemptive (i.e. addressing an actual or perceived gap in the students' knowledge). 
(FonF) is often contrasted with (FonM) exemplified by Krashen. However, Long's and Krashen's approaches have some similarities. They are both types of implicit language instruction in which the main focus is on meaning, with no rules given and no overt directions to attend to any given form. A major difference is that Long's TBLT diverts students' attention to specific forms that arise incidentally when a communication breakdown occurs for a student. While the term form is often taken to refer exclusively to grammar, Laufer (2005) maintains that (FonF) can be directed at phonology, vocabulary, grammar, or discourse. Nassaji and Fotos (2004) believe that it was Krashen who represented the debate theoretically by suggesting the distinction between conscious learning and unconscious acquisition of language. It was claimed that language should be acquired through natural exposure, not learned through formal instruction. It was therefore believed that formal grammar lessons would develop only declarative knowledge of grammar structures, not the procedural ability to use forms correctly, and that there was no interface between these two types of knowledge since they existed as different systems in the brain.

\section{The Role of L1 in Grammar Instruction}

Based on the Tasked-Based Language Teaching/learning methodology, the assumption that the learner's first language (the L1) is a deterrent in foreign language learning is challenged and modified. According to Canagarajah (1999) the belief that use of the learner's native language interferes with the learning of English and hampers the process of second language development has now passed into the realms of pedagogical common sense. The inclusion of the L1 is thus described as a resource in foreign language teaching in general and in teaching the grammar in particular. As Tollefson (2000) points out it is a process which aims to 'empower learners by putting their experiences and knowledge at the center of the pedagogical process' (p. 146). In the same vein, by reporting learners' positive perceptions of first language (L1) incorporation in foreign language teaching and learning contexts, Swain and Lapkin (2001) do not support the theory and practice of the inclusion of L1 in EFL classrooms.

However, the debate on the inclusion of the L1 in EFL classes is still continued. For many researchers and instructors who are hesitant to the use of the native language in the foreign language classes, the L1 can ultimately be seen as teaching tool especially in realm of the grammar instruction than a learning tool.

\section{METHOD}

\section{A. Participants}

A total of 128 students in four high schools in Isfahan province, the city of Falavarjan as well as 5 instructors who taught EFL at these high schools took part in this study. The age range of the students was 15-18. There was no sample selection and all the students were included in the study.

\section{B. Instruments}

Instrumentation included a semi-structured interview and a questionnaire (designed for the students and the instructors). At the beginning of the study, interviews were conducted with the students and the instructors. A list of questions regarding such issues as different approaches to grammar teaching and their application in an EFL context in general and in the grammar instruction in particular emerged to see what kind of grammar teaching can effectively facilitate language learning.

Then a closed-response yes-no questionnaire (Appendix A) was designed. The interview data also provided input for adding extra items mainly with regard to learners' preferences for the best instructional method they can receive in Iranian context.

\section{Procedures}

For the ease of students and instructors, the three instructional methods, i.e., (FonFs), (FonF), and (FonM) were thoroughly explained. The questionnaire was also administered and responded to in Persian. The questionnaire aimed to explore the opinions of the students on their expressed views toward learning grammar. It also aimed to seek the instructors' attitudes concerning the evaluation of different grammar instruction methods.

The filled in questionnaires were then analyzed. The frequency and the percentage of positive and negative viewes towards each question was computed and compared.

\section{RESULTS AND DISCUSSION}

Of the 128 respondents, $116(90 \%)$ reported having preferred FonF instructional method and only12 (9\%) were disagree with this method. The results also revealed that more than $95 \%$ of the participants believed that the contextual considerations such as, the requirements of the class syllabus and final exams, shortage of time allotted to language classes and their inability to communicate in English and the need to incorporate L1 into instruction were responsible for their choice. The results of the questionnaires are presented in table 1. Only 16 (12\%) favored a FonFs approach, and almost no student $2.3 \%$ thought they could benefit from a merely FonM instructional method. The opinions of teachers mentioned with regards to the question were mainly the same as the students. 
TABLE I.

LEARNERS' OPINION ABOUT DIFFERENT GRAMMAR INSTRUCTIONAL METHODS

\begin{tabular}{|l|l|l|l|l|l|}
\hline & questions & $\begin{array}{l}\text { Agree } \\
\text { (Yes) }\end{array}$ & percent & $\begin{array}{l}\text { Disagree } \\
\text { (No) }\end{array}$ & percent \\
\hline $\begin{array}{l}\text { (FonFs) } \\
\text { Focus on Forms }\end{array}$ & $\begin{array}{l}\text { Focus on forms lead to the acquisition of a significantly larger number } \\
\text { of grammatical points. }\end{array}$ & 16 & 12.2 & 114 & 89 \\
\cline { 2 - 6 } & $\begin{array}{l}\text { Planned, explicit, and discrete- point metalinguistic explanations is } \\
\text { more effective. }\end{array}$ & 18 & 14 & 110 & 85 \\
\hline $\begin{array}{l}\text { (FonF) Focus on } \\
\text { Form }\end{array}$ & $\begin{array}{l}\text { Focus on form lead to the acquisition of a significantly larger number } \\
\text { of grammatical points. }\end{array}$ & 116 & 90.6 & 12 & 9.3 \\
\cline { 2 - 6 } & $\begin{array}{l}\text { Incorporating grammatical explanation into a communicative lesson } \\
\text { make a significant difference in acquiring new grammatical points. }\end{array}$ & 118 & 92.1 & 10 & 7.8 \\
\hline $\begin{array}{l}\text { (FonM) Focus } \\
\text { on Meaning }\end{array}$ & $\begin{array}{l}\text { Focus on meaning lead to the acquisition of a significantly larger } \\
\text { number of grammatical points. }\end{array}$ & 3 & 2.3 & 125 & 97.6 \\
\cline { 2 - 6 } & Implicit, unplanned, and incidental references to form is effective. & 5 & 3.9 & 123 & 96 \\
\hline \multirow{2}{*}{ Others } & $\begin{array}{l}\text { Incorporating translation activities make a significant difference in } \\
\text { acquiring new grammatical points. }\end{array}$ & 120 & 93 & 8 & 6.2 \\
\cline { 2 - 6 } & $\begin{array}{l}\text { The limitation of the class time is responsible for the choice of the } \\
\text { preferred instructional grammar method. }\end{array}$ & 122 & 95 & 6 & 4.6 \\
\cline { 2 - 6 } & $\begin{array}{l}\text { Problems in speaking and listening are responsible for the choice of } \\
\text { the preferred grammar instructional method? }\end{array}$ & 117 & 91 & 11 & 8.5 \\
\cline { 2 - 6 } & $\begin{array}{l}\text { The requirements of the syllabus and final exam are responsible for } \\
\text { the choice of grammar instructional method. }\end{array}$ & 125 & 97.6 & 2 & 1.5 \\
\hline
\end{tabular}

\section{CONCLUSION}

The findings of the study indicate that a type of grammar instructional method in which attention to grammatical forms happens in the context of communication is favored. The (FonF) instruction along with the incorporation of a limited amount of L1 was favored by more than two thirds of the students. They liked the fact that this approach is completely student centered and they can somehow control the forms to be taught.

However, in line with Ellis (1995), the inconclusive natures of L2 acquisition studies of the best way to teach grammar suggest that it is premature to reach any firm conclusion regarding what type of formal instruction work best. The results of the study cannot be generalized due to its own limitations. The fact that EFL/ESL methodologists have not yet offered consistent advice to teachers about the role of grammar in language teaching has frustrated teachers who cannot decide between many conflicting positions in the methodological literature. On the one hand, it is now believed that a grammarless approach- whether comprehension-based or communicative-based can lead to the development of a broken, ungrammatical, pidginized form of the target language. On the other hand, the debate regarding how to teach grammar presents a dilemma for many teachers.

Similarly, in the Iranian context the concern over finding the most valid, reliable and trustworthy grammar teaching method has still remained a controversial issue. The findings of this study can shed light in this issue by showing that, in the Iranian EFL context, (FonF) instructional approach which emphasizes focus on meaning with attention to form is favored over a (FonF) approach which is equated with the traditional teaching of discrete points of grammar in separate lesson and (FonM) approach which emphasizes comprehensible input and meaning oriented tasks as necessary and sufficient for language acquisition. This kind of language learning and teaching perspective, i.e., (FonF) is not however fully implemented because of the Iranian contextual considerations such as, the requirements of the class syllabus and final exams, shortage of time allotted to language classes, the failure to have meaningful communication outside the language classes, and the kind of teacher training programmes in Iran. Moreover, in the Iranian context, English language classes have long been teacher-fronted ones with teachers playing active roles and serving as one of the major sources of input. They provide explicit instruction of grammar to somehow manifest their power and knowledge.

In summary, grammar cannot be discarded from foreign language pedagogy since form and meaning cannot be excluded. While the efficacy of the (FonF) instruction for the Iranian EFL context needs empirical evidence, adopting a (FonF) approach as a modification of communicative language teaching which is in line with the learners' needs to communicate meaningfully and effectively can be a preferred option. The results suggest that the treatment of grammar with a 'one -size -fits- all' methodology instead of utilizing a balanced perspective based on the needs and context of the learners can yield insufficient result in any language teaching contexts.

\section{Implication of the Study}

The results of the study can provide implications for the choice of the most effective instructional approaches in teaching grammar in different contexts and in particular in the Iranian high school EFL context. Because of problems presented by traditional structure-based grammar teaching which involves presenting discrete grammatical forms in an isolated manner, the result of this study is in line with applying Longs' (1991) focus on form approach which involves the teacher's attempts to draw the student's attention to grammatical forms in the context of communication. Since the use of (FonFs) instruction means that the communicative classroom is abandoned, a return to the grammar translation method at the expense of the ability to function in a foreign language is not recommended. By considering the present social, educational, and cultural context of the Iranian students and raising both students' and instructions' awareness 
towards them, a middle way, i.e., (FonF) approach between the two extremes of (FonFs) and (FonM) instructions can be effectively utilized in high school EFL classes in Iran.

\section{APPENDIX A STUDENTS' QUESTIONNAIRE}

Dear Participants,

The following questionnaire is part of a research project that aims to explore the students and instructors expressed views and attitude towards grammar instruction methods.

Background Information

1. Name and family name: (optional)

2. Age - years

Please tick (Y) for Yes and $(\mathrm{N})$ for No for each question.

1. Does focus on forms lead to the acquisition of a significantly larger number of grammatical points?

(Y) $\square \quad(\mathrm{N}) \square$

2. Are planned, explicit, and discrete- point metalinguistic explanations effective?

(Y) $\square \quad(\mathrm{N}) \square$

3. Does a focus on form lead to the acquisition of a significantly larger number of grammatical points?

(Y) $\square \quad(\mathrm{N}) \square$

4. Does incorporating grammatical explanation into a communicative lesson make a significant difference in acquiring new grammatical points?

\section{(Y) $\square \quad(\mathrm{N}) \square$}

5. Does a focus on meaning lead to the acquisition of a significantly larger number of grammatical points?

(Y) $\square \quad(\mathrm{N})$

6. Are implicit, unplanned, and incidental references to form effective?

\section{(Y) $\square \quad(\mathrm{N}) \square$}

7. Do incorporating translation activities make a significant difference in acquiring new grammatical points?

(Y) $\square \quad(\mathrm{N})$

8. Does the limitation of the class time affect instructors' choice of instructional grammar method?

(Y) $\square \quad(\mathrm{N}) \square$

9. Does the instructors' deficiency in speaking and listening affect the choice of grammar instructional method?

(Y) $\square \quad(\mathrm{N})$

10. Do the requirements of the syllabus and final exam affect the choice of grammar instructional method?

(Y) $\square \quad(\mathrm{N})$

\section{REFERENCES}

[1] Brown, J. D. (2001). Using surveys in language programs. Cambridge: Cambridge University Press.

[2] Campbell, R. (1970). An evaluation and comparison of present methods for teaching English grammar to speakers of other languages. TESOL QUARTERLY, 4/1, 37-48.

[3] Borg, S. \& Burns, A. (2008). Integrating grammar in adult TESOL classrooms. Applied Linguistics, 29/3, 456-482.

[4] Canagarajah, A. S. (1999). Resisting linguistic imperialism in English teaching. New York: Oxford University Press.

[5] Celce- Murcia, M. (1991). Grammar pedagogy in second and foreign language teaching, TESOL QUARTERLY, 5/3, 459-480.

[6] Cullen, R. (2008). Teaching grammar as a liberating force. ELT Journal, 62/3, 221-230.

[7] Davies, M. (2006). Paralinguistic focus on form. TESOL QUARTERLY, 40/4, 841-850.

[8] Ellis, R. (1995). Interpretation tasks for grammar teaching. TESOL QUARTERLY, 29/1, 87-105.

[9] Ellis, R. (2003). Task-based language learning and teaching. Oxford; Oxford University Press.

[10] Ellis, R. (2006). Current issues in the teaching of grammar: An SLA perspective. TESOL QUARTERLY, 40/1, $157-181$.

[11] Ellis, R. et al. (2001). Preemptive focus on form in the ESL classroom. TESOL QUARTERLY, 35/3, 407-420.

[12] Fotos, S. S. \& Ellis, R. (1991). Communicating about grammar: A task-based approach. TESOL QUARTERLY, 25/4, 605-628.

[13] Fotos, S. S. (1994). Integrating grammar instruction and communicative language use through grammar consciousness raising tasks. TESOL QUARTERLY, 28/2, 323-331.

[14] Harmer, J. (2003). Popular culture, methods, and context. ELT Journal, 57/3, 288-294.

[15] Larsen-Freeman, D. (2003). Teaching language: From grammar to grammaring. Boston: Heinle \& Heinle.

[16] Larsen-freeman, D. (2000). Teaching and principles in language Teaching. Oxford University Press, pp. 11-22.

[17] Laufer, B. (2005). Focus on form in second language vocabulary learning. EUROSLA, 5, 223-250.

[18] Laufer, B. and Girsai, N. (2008). Form-Focused instruction in second language vocabulary learning. Applied Linguistics, 29/4, 694-716.

[19] Light, T. (1968). The three dimensions of grammar for teaching English as a foreign language. TESOL, 2.4, 219-225.

[20] Long, M. (1991). Focus on form: A design feature in language teaching methodology. In K. DeBot, R. Ginsberg, \& C. Kramsch (Eds.), Foreign language research in cross-cultural perspective (pp. 39-52). Amsterdam: Benjamins

[21] Long, M. (1991). Focus on form: A design feature in language teaching methodology. In K. DeBot, R. Ginsberg, \& C. Kramsch (Eds.), Foreign language research in cross-cultural perspective (pp. 39-52). Amsterdam: Benjamins.

[22] Nassaji, H. \& Fotos, S. (2004). Current development in research on the teaching of grammar. Annual Review of Applied Linguistics, 24/2, 126-145. 
[23] Martin, M. A. (1978). The application of spiraling to the teachers' grammar. TESOL QUARTERLY, 12/2, 151-161.

[24] Brooks-Lewis, K. A. (2009). Adult Learners' Perceptions of the Incorporation of their L1 in Foreign Language Teaching and Learning. Applied Linguistics, 30/2, 216-235.

[25] Richards , J. C. \& Rodgers, T. S. (2001). Approaches and methods in language teaching. Cambridge.

[26] Saraceni, M. (2007). Meaningful form: transitivity and intentionality. ELT Journal, 62/2, 1-9.

[27] Sheen, R. (2003). Focus on form- a myth in the making? ELT Journal, 57/3, 225-234.

[28] heen, R. (2006). Comments on R. Ellis's "Current issues in the teaching of grammar: An SLA perspective". TESOL Quarterly 40/4, 828-32.

[29] Swain, M., \& Lapkin, S. (2001). Focus on form through collaborative dialogue: Exploring task effects. In M. Bygate, P. Skehan \& M. Swain (Eds.), Researching pedagogic tasks: Second language learning, teaching and testing (pp. 99-118). Harlow, UK: Pearson Education.

[30] Tollefson, J. W. (2000). 'Policy and ideology in the spread of English' in J. K. Hall and W. G. Eggington (eds): The Sociopolitics of English Language Teaching. Buffalo: Multilingual Matters Ltd.

Fatemeh Abbasian Boroujeni is a Ph.D. candidate in Applied Linguistics at Isfahan University, Isfahan, Iran. She has taught English to EFL students for more than 10 years at high schools and Teacher Training centres of Isfahan, Iran. Her research interests are EFL teaching and learning and needs analysis. 